\title{
Towards Sustainable Interior Design Education in Egypt
}

\author{
Rasha Mahmoud El-Zeney \\ Faculty of Fine Arts, \\ Minia University, Egypt \\ rashaelzeney@yahoo.com
}

\begin{abstract}
The need to introduce issues of sustainability into the interior design curriculum has become critically important. So the purpose of this study was to investigate the current status of teaching sustainability in curricula of interior design programs in Egypt's universities; assess the level of awareness and training background on sustainability and determine the obstacles to incorporating sustainability into the programs. Interior design lecturers, professors were invited to participate in a survey on their university's interior architecture curricula. The study shows that all interior design programs currently do not teach sustainability within their curricula, and there are some obstacles in teaching sustainability.
\end{abstract}

Keywords: Sustainability, Interior design, Egypt, Education

eISSN 2514-751X @ 2017 The Authors. Published for AMER ABRA by e-International Publishing House, Ltd., UK. This is an open-access article under the CC BY-NC-ND license (http://creativecommons.org/licenses/by-ncnd/4.0/). Peer-review under responsibility of AMER (Association of Malaysian Environment-Behaviour Researchers), ABRA (Association of Behavioural Researchers on Asians) and cE-Bs (Centre for EnvironmentBehaviour Studies), Faculty of Architecture, Planning \& Surveying, Universiti Teknologi MARA, Malaysia.

https://doi.org/10.21834/aje-bs.v2i5.227 


\subsection{Introduction}

The need to introduce issues of sustainability into Interior Design curricula has become critically important. The year 2005 marks the commencement of the United Nations Decade of Education for Sustainable Development, which is an opportunity as well as a challenge for educators of all stripes to reorient their teaching, research, and community outreach towards sustainability. Another motivation is the Talloires Declaration, a ten-point sustainability and environmental literacy action plan to which over 300 university leaders worldwide are committing their institutions, one point of which is "ensuring that all university graduates have the awareness and understanding to be ecologically responsible citizens" (ULSF, 1990).

Since interior designers play a vital role in the creation of our built environment, then it is imperative that students, who are our future designers, become aware of how their attitudes, behaviors and actions will impact our future natural environment and the health of people. There can be no responsible design without a responsible designer (Findeli, 2001). Hence design education should be redirected to the development of an ethical designer, one who could think and radically "design out design that delivers environmental problems" (Fry, 1993).

So how has the interior design education in Egypt responded to this challenge for responsible and sustainable solutions? This and other related questions are the focus of this paper. It further recommends some future strategies to achieve the Integration of sustainability in Egyptian Interior Design Education.

\subsection{Literature Review}

Sustainability, sustainable design, ecological design, green design, eco-design, environmental design, etc. are all terms used when discussing designing with concern for the environment. With all these terms, it can be confusing for designers to know where to look for information. The Forestry Service (2007) claimed that a specific definition of sustainability that is universally accepted is difficult because it varies among groups with different values and over time.

To simplify the many terms surrounding sustainability, we can use the definition that most individuals accept which is "meeting the needs of the present without compromising the ability of future generations to meet their own needs", which was written by the World Commission on Environment and Development as Burndtland Report (1987) entitled Our Common Future.

\section{Roles for interior designers}

Sustainable design had a lot of mystery and misinformation surrounding it due to the newness of the topic. Flynn (2007) claimed "Because the demand for sustainable design is relatively recent 
and still growing, many people do not have the experience with the processes, methods, and ideas that sustainability requires... because of this clients are looking even more to us as design professionals to lead the process".

Designers carry a heavy burden in regards to practicing sustainable design. According to Lapiana (2006), sustainability is not just about 'green' materials. It also includes energy efficiency, longevity over generations, and the ability to think locally as well as globally. Bonda (2007) argued that interior designers and architects have responsibilities beyond the average person because they have an obligation to recognize the long-term effects of their designs. Similarly, Chermayeff (1982) stated that being a designer comes with great responsibility. "Those who understand the power of design know it is a highly developed problem-solving discipline, a skill whereby complex problems with many competing requirements can be transformed into elegant solutions" (Battisto, 2001, p. 5).

\section{Sustainable design education}

Education provides interior designers the base knowledge required to practice within the field. Some suggest the interior design curriculum could include sustainable design principles. Whitemyer (2007: p. 16) stated, "Education more than anything else is what will push green design into mainstream". Higher education remains the foundation from which a sustainable society can grow. Second Nature Inc. (2005), higher education in the $21^{\text {st }}$ century has challenged educators to prepare and educate their students about the environmental impact held by each individual.

According to Krasner (1980), "In the Environmental Education Act of 1970 (Public Law 91-516) environmental education is defined as "the educational process dealing with man's relationship with his natural and man-made surroundings, and includes the relation of population, pollution, resource allocation and depletion, conservation, transportation, technology and urban and rural planning to the total human environment."

Educational programs in architecture, engineering, and interior design need sustainability to be taught within their curricula. Gould (2002: p. 3) argued "Schools of architecture, interior design and engineering should rewrite their mission statements, hire and tenure environmental professionals as teachers,". Gould (2002) also claimed that the interior design profession needed rational undergraduate training, continuing education opportunities and support to provide research in sustainability.

An interior design curriculum that incorporates sustainability content offers students an additional instrument to use within the design process. Bainbridge (2002) stated "Incorporating ecology in education is both possible and essential. Students and design professionals need to understand the whole to improve the parts, [they should be] learning that actions have effects, and that problems can't be solved in isolation.

The Interior Design Educators Council's (IDEC) Sustainable Design Task Force has offered another vision of how sustainable principles might be incorporated. According to Stieg (2006), they suggested McDonough and Braungart (cradle to cradle) recommendations for 
integrating sustainable design principles into the undergraduate curriculum

Similarly, interior design accreditation through the Council for Interior Design Accreditation (CIDA) has modified its requirements to include sustainable design education. CIDA (formerly known as FIDER) accreditation guidelines require sustainability within the programs' curriculum. Environmental ethics, sustainability, sustainable building methods and materials, green design, and indoor air quality are specifically referenced goals in five of the nine standards, suggesting that the subject should be addressed throughout the curriculum (CIDA, 2006).

\section{Current practice in Egyptian interior design education}

So how has the Interior Design Education community in Egypt responded to this challenge for responsible and sustainable solutions? What is the current status of sustainability in interior design curricula? Are academics and students interested in sustainable design, and if they are, do they apply those in their teaching? How have educators prepared themselves to teach sustainability to interior design students? What are the obstacles to incorporating sustainability into interior design programs?

The current practice in teaching sustainability in Egyptian Interior Design Education is being investigated to answer these questions. The discussions in this section are based on a survey to assess the level of awareness and training background on sustainability.

\subsection{Methodology}

To shed further light on these issues in the context of Egyptian Interior Design Education, and gather data regarding the educators' attitudes about sustainability, a questionnaire survey was fielded to 87 academic staff in all the faculties that offered undergraduate degrees in interior architecture or interior design ( 5 faculties). These faculties were: Faculty of Fine Arts, Helwan University, Faculty of Fine Arts, Alexandria University, Faculty of Fine Arts, Alexandria University, Faculty of Fine Arts, Minia University, Faculty of Fine Arts, Luxor University.

Forty-seven academics (54 per cent), replied, and all 5 Faculties have been represented by at least 3 respondents. The reason for non-response could be the usual lack of available time or interest to participate in surveys. This study recognizes that some respondent bias could be present, since the more ecologically passionate academics were more likely to answer than those who are less concerned with these issues. Statistical analysis on the data was done using SPSS Version11.5 software. All survey participants will remain anonymous.

Due to the fact that sustainable design education in interior design programs is a new area in Egypt, the study could be limited by the lack of qualified educators as well as the lack of resources. So three interviews with architectural professors who concern and teach sustainability was used to provide qualitative data on educators' opinions regarding 112 
sustainable design education and how to incorporate it into the curriculum.

\subsection{Results And Discussions}

This section will present the results that emerged from the study. These results summarize the data collected for the survey and the interviews. The study has revealed many things about the current status of sustainability within interior design programs in Egypt.

\section{Current status of sustainability in interior design curriculum in Egypt}

The data has revealed that all the interior design programs in Egypt do not teach sustainability in their curriculum. The Survey showed that all the respondents (100\%) responded "no" to the question asking if sustainability is taught in their interior design program (see Figure 1). However three of the respondents incorporated some aspects of sustainability in some courses by personal initiative.

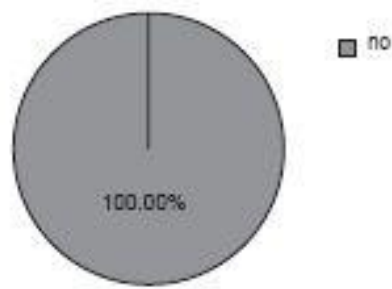

Figure 1: Teaching sustainability in the curriculum

Despite the obvious need for the sustainable design education, The Egyptian interior design programs have not integrated these issues into the curriculum, while, various design education surveys and studies in many countries done in the disciplines of architecture (Zalina Shari1 and Mohd Fakri Zaky Jaafar 2006), interior design (Metropolis, 2003; Elliot, 2004; Ramirez, 2006) and mixed design disciplines (Metropolis, 2002) have generally shown that sustainability issues are penetrating into core design programs.

So our first recommendation on the need to emphasize the importance of integrating sustainability in an interior design program with sustainability components explicitly stated in the curriculum.

\section{Educators' interest in sustainability}

The interest in sustainability varied among the educators. Contrary to the expectations, $(48 \%)$ of the respondents were very interested in sustainability and $(45 \%)$ of them were interested, however $(5 \%)$ respondents were neutral and $(2 \%)$ were not interested (see Figure 2). The majority of faculty also felt that their students were either not interested or neutral in the topic, (see Figure 3). 


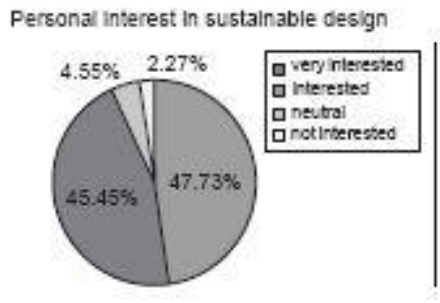

Figure 2: Educators' interest in sustainability

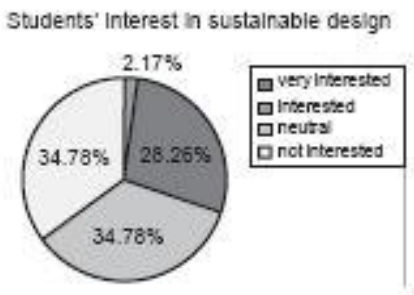

Figure 3: Students' interest in sustainability

\section{Motivations for teaching sustainability}

The study showed that the majority of the teaching faculty $(79 \%)$ is willing to teach sustainability, (see Figure 4), and many of them have a passion for the environment. This passion motivates these educators to learn about sustainability and to teach it. Many of the faculty felt that their personal interest in the environment is a motivating factor in their willing to teach sustainability.

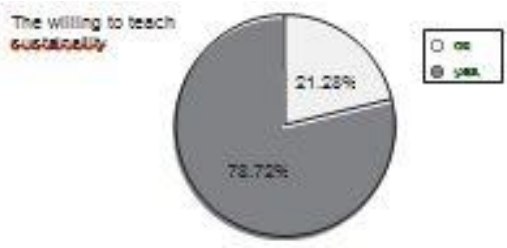

Figure 4: Willing to teach sustainability

\section{Sustainability in teacher education}

In order for sustainability to be successfully embedded in interior design education, it is only logical to expect the educators to be adequately informed and knowledgeable in sustainability themselves. This section examines issues of the preparedness among educators with regards to sustainability knowledge. It was found that $(20 \%)$ of respondents considered themselves very prepared to teach sustainable design, and $(47 \%)$ felt prepared, however $(26 \%)$ of respondents considered themselves as being not adequately informed about aspects of sustainable design, (see Figure 5).

Since sustainability has been viewed as a new and trendy movement within the interior design profession and in the general public, the study showed that most faculty were self-taught in sustainability, utilizing browsing through the internet $(55 \%)$ and reading related books and scientific papers for information (34\%), however (8\%) of respondents had the opportunity to attend conferences, do or supervise postgraduate theses on sustainable 
design, (see Figur 6).

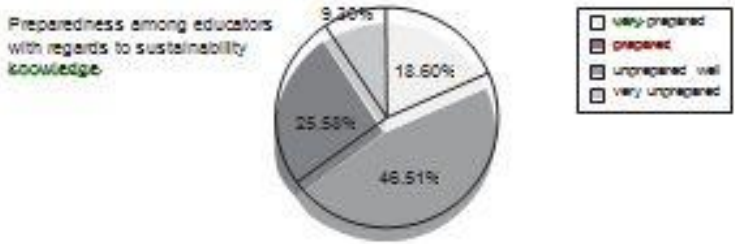

Figure 5: Preparedness among educators

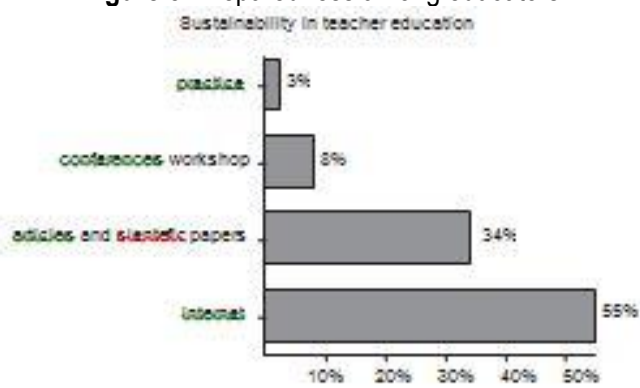

Figure 6: Sustainability in teacher education

Attending programs i.e. courses, seminars, workshops, symposia, conference or other modes of continuing education, are still not the prevailing means to increase respondents' knowledge on sustainability. A possible explanation could be that there is a scarcity of such programs related to sustainability being held in Egypt. Therefore, our second recommendation is for the universities and faculties to organize continuous and systematic training programs to increase the sustainable literacy among interior design educators.

\section{Sustainability integration into the program}

The study showed that the majority of Interior Design Academics did not encourage sustainability as a "stand-alone" course. As the data has indicated, (67\%) of respondent thought sustainability is better taught throughout a curriculum so that multiple aspects of it can be covered by various courses utilizing different educators' perspectives on the topic. The findings indicated that educators felt that if sustainability is offered as a separate course the students will view it as an option and not a requirement within their other course work, (see Figure 7). 


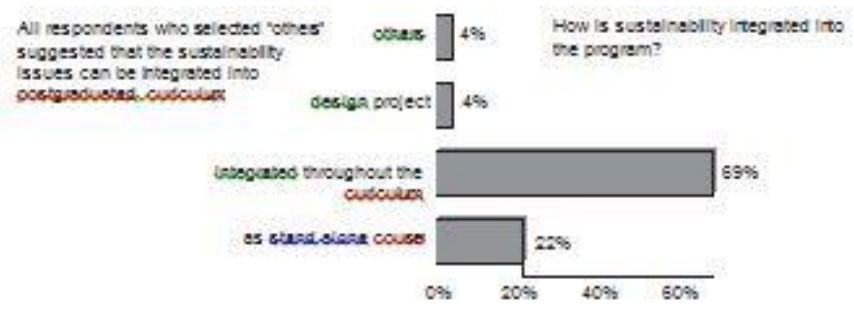

Figure 7: Sustainability integration into the program

The interviews revealed that the basic principle of a holistic approach to sustainable design within the design curriculum is preferred by the educators, and this approach has many possible advantages, whereas incorporating sustainability into the curriculum allows educators to teach many different components by covering them in many classes. Materials and technology courses cover sustainable materials and life-cycle analyses, design courses cover application of sustainability in the design process, and lecture courses discuss the social, ethical and personal responsibilities of the interior designer.

So the third recommendation is that the holistic approach to sustainable design within the Interior Design curriculum is preferred, because the different courses allow for multiple aspects of sustainability to be covered without forcing it all into one course.

Many of the faculty felt that sustainability should be introduced into the Interior Design curriculum since year $3(49 \%)$ or year $4(7 \%)$, where the situation improves as students progress into the upper years, while the other respondents seem to disagree with the trend and suggested that sustainability teaching must also be emphasized during the foundation years, $(19 \%)$ suggested that it should be introduced since year 1and $(16 \%)$ suggested that it should be introduced since the freshman year (see Figure 8 ).

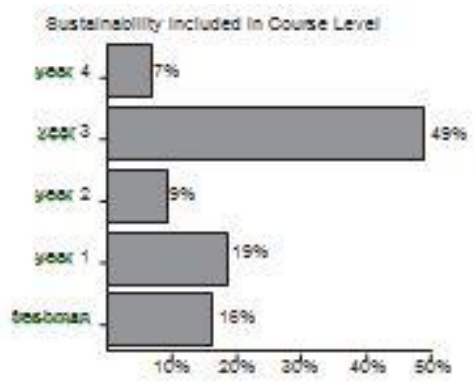

Figure 8: Sustainability in course level

The interviews revealed that it should be introduced as early as the freshman year, these educators also felt that the various topics of sustainability should be taught 116 
throughout the interior design program at every level. Therefore, our fourth recommendation is to formulate a strategy on how we can increase the level of sustainability awareness among lower year students in Egypt.

\section{Obstacles in teaching sustainable design}

The study indicated that there are many obstacles which were identified and categorized into 6 different categories: Educator, Resource, Government, Student, Curriculum, and subject.

\section{Educator's Factors}

The most cited obstacles fall predominantly under the category of 'educator's factors'. Among the specified barriers under this category are the lack of awareness, interest and enthusiasm by other faculty and the lack of exposure or knowledge; lack of training/education in sustainable design. Studies by Yang and Giard (2001) and Metropolis (2002) state that the lack of academic staff training as well as the lack of time for education are two frequently cited obstacles against integrating sustainability themes into design education.

\section{Resource Factors}

Among the barriers are the shortage of sustainable building literature and effective textbooks covering the subject matter in local libraries, in addition to the scarcity of sustainable building examples in Egypt.

\section{Government Factors}

The lack of and enforcement by the government regarding any issues of sustainability as well as the lack of agencies promoting the issues are among the barriers to promote sustainability in the interior design education.

\section{Student Factors}

The barriers are related to attitude and linked mainly to the lack of interest and understanding on the issues of sustainability.

\section{Curriculum Factors}

It is often described as being saturated already with little scope for additional content. The limited space and time inside the interior design curriculum is an important obstacle in integrating sustainability due to the amount of information that needed to be covered within the limited size and time frame of most programs. The study indicated that the courses also are difficult to embed sustainability, due to their existing content and purpose. This issue is complex but there seems to be evidence that few academics are trying to incorporate sustainability in the teaching of some subjects. 


\section{Subject Factors}

Several issues relating to the subject matter of sustainability itself were identified. One problem expressed by respondents was that the breadth and complexity of sustainability issues was beyond their understanding. Taking a wide view of related comments, there is a possible inertia among educators due to the difficulty in trying to make sense of the 'abstract' and then moving to 'doable' projects. Some respondents even considered that sustainability is merely 'fashionable'. Others regarded sustainable development as 'specialist', and 'complex', requiring expert knowledge to make good decisions.

\subsection{Conclusions}

To promote 'sustainability' in Egyptian Interior Design Education, we introduce some recommendations extracted from the study, which can be summarized as follows:-

[ᄄ The existing curricula in our programs should be reviewed and revised in order to promote 'sustainability' in interior design education.

[u Organize raining programs, i.e. seminar, conference, training, courses and etc. to increase awareness among students and academics on issues of sustainability.

[u The incorporation of sustainability must be at the earliest stage possible in interior design programs.

[ᄄ Sustainability must not be limited to just material and product specifications, but should involve more holistic approaches.

[ᄄ] More research was needed in sustainability within interior design. The types of research must vary from material research, to human behavior, to predict if people would change their habits, further researches that address the issues of sustainability are to be given more emphasis by universities.

ㄷ․ On the regulatory aspect, explicitly embedding sustainability requirements in by-laws would govern more practicing architects, interior designers and educators to instill sustainability in their projects and teachings.

[0 The Government's step to develop more real life sustainable projects is also highlighted as an effective move towards enhancing public's awareness on the importance of sustainability in the built environment.

[ The local media must play a role in generating more public awareness towards environmental sustainability.

\section{References}

Bainbridge, D.A. (2002). Ecology and education for sustainable design. Retrieved January 19, 2007, from the Ecology and Education for Sustainable Design Web site: http:// www.ecocomposite.org/building/eesd.htm. 
Bruntland, G. (Ed.). (1987). Our common future: The world commission on environment and development, Oxford, England: Oxford University Press.

Council for Interior Design Accreditation (CIDA) (2007). Who we are? Retrieved October 28, 2007, from the CIDA Web site: http://www.accredit-id.org/who.htm.

Elliott, J. (2004). Teaching sustainability to tomorrow's interior designers, Metropolis, available at: www.metropolismag.com/html/sustainable/case/tomorrows interiordesigners.html.

Gould, K.L. (2002, November). Teaching green: Design with values. Retrieved March 7, 2007, from MetropolisMag.com Web site: http://www.metropolismag.com/html/ content_1102/sup/index.html.

Findeli, A. (2001). Rethinking design education for the 21st century: theoretical, methodological, and ethical discussion, Design Issues, 19(1).

Fowles, B., Corcoran, M., Erdel-Jan, L., Iball, H., Roaf, S. \& Stevenson, F. (2003). Report of the Sustainability Special Interest Group (Architectural Education), Centre for Education in the Built Environment, London.

Fry, T. (1993). Re-thinking ecodesign, Object, Vol. 43.

Hutchison, D. (1998). Growing up green: education for ecological renewal. Columbia University, NY: Teachers College Press.

Krasner, L. (Ed.). (1980). Environmental design and human behavior. New York: Pergamon Press.

Metropolis (2002). Teaching green: making sustainability integral to every designer's education \& business, Metropolis, 22(3).

Nguyen, D.Q. \& Pudlowski, Z.J. (1997). A comparative study of the perspectives of academics, students and industry on environmental education in engineering courses, Global Journal of Engineering Education, 1(3).

Shari, Z. \& F. Z. Jaafar (2006). Integration and Implementation of Sustainability in Malaysian Architectural Education. The 40th Annual Conference of the Architectural Science Association ANZAScA, 22-24 November 2006 Adelaide, Australia.

Stegall, N. (2006). Designing for sustainability: A philosophy for ecologically intentional design. Design Issues, 22(2): 56-63.

Stieg, C. (2006). The sustainability gap. Journal of Interior Design, 32(1), vii-xxi.

ULSF (1990). Talloires Declaration: University Presidents for a Sustainable Future, University Leaders for a Sustainable Future, Talloires FR. http://www.ulsf.org/ programs_talloires.html

White Myer, D. (2007). The road to green. Perspective, Winter, 9-19.

Yang, Y. \& J. Giard (2001). Industrial design education or sustainability: structural elements and pedagogical solutions. Paper presented at the IDSA National Design Education Conference, Boston, MA. 